\title{
Attitude of Individual Investors towards Commodity Trading in Disruptive Technological Era
}

\author{
R. Gopinath, M. Vasan, M. Sumathy
}

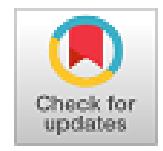

\begin{abstract}
The commodity future trading is one of the major investment avenues. But, still the people are preferred to conventional investment avenues like gold and real assets. At this juncture, the present study has focused on attitude and satisfaction of investors towards commodity market. Thus, this study helpful to understand the preferred commodity, objectives of investment, techniques for managing risks, reasons for investing in commodities and problems in commodity trading. The study identified that investors are invested in commodities as well as other diversified investment avenues. Low risk is a prime reason for investing in the commodities. The investors are highly satisfied with the return from the commodity trading. The study results helpful to the financial planners and brokers for understanding pulse of the investors.
\end{abstract}

Keywords: Commodity Trading, Future Trading, Investors Behaviour, Commodity Exchange.

\section{INTRODUCTION}

The commodity market is one of the important constituent of financial market. It deals the spectrum of products namely metals, crude oil, precious metals, energy and soft commodities such as coffee, wheat, cotton, palm oil, spices, coffee, etc. There are about 120 products traded in the commodity market. It is an organized market for selling standardized products. Most of the market operations are concerned with the nature of future contracts. This futures trading is an easiest way for the investors to get capital investments [1]. The globalization of economy has increased business opportunities across the globe particularly in developing countries like India. This business growth has created new job opportunities which increased the income of individuals and they find better investment avenues to park their surplus. So, the more number of individual investors are trading in the commodity market [2]. The commodity market influences on economic growth and development of India. In recent past, the people are preferred to invest in the financial

Revised Manuscript Received on August 30, 2019.

* Correspondence Author

Dr. R. Gopinath*, Visiting Faculty, Bharathidasan School of Management, Bharathidasan University, Trichy.

Dr. M. Vasan, Assistant Professor of Commerce, A.V.V.M. Sri Pushpam College (Autonomous), Poondi, Thanjavur Dt. Tamilnadu, India.

Dr. M. Sumathy, Dean, Professor \& Head, School of Commerce, Bharathiar University, Coimbatore, Tamilnadu, India.

(C) The Authors. Published by Blue Eyes Intelligence Engineering and Sciences Publication (BEIESP). This is an open access article under the CC BY-NC-ND license (http://creativecommons.org/licenses/by-nc-nd/4.0/) market. It is due to literacy rate, increase in middle income group, increase in earning capacities, disposal of surplus income, saving habits and awareness on financial instruments. However, the people are uninterested to take risk so most of them hesitated to invest in the financial markets [3].

In India, the various investment avenues are available to the investors. They are: equities, derivatives, debentures, bonds, commodities, etc. Every financial product has its own risks. Investors are selecting financial products according to their own perception, return and risk preferences. Some of them successfully harvested benefits from financial products. The commodity future trading is a one of the major investment avenue [4]. But, still the people are preferred to conventional investment avenues like gold and real assets. At this juncture, it is important to study the behaviour of investors towards commodity market. Thus, understand the preferred commodity, objectives of investment in commodity market, techniques for managing risks, reasons for investing in commodity market and problems in commodity trading. The study results are helpful to the financial planners and brokers for understanding pulse of the investors.

\section{LITERATURE REVIEW}

Kapil, et. al (2010) focused on the major operational and policy issues in the growth of commodity market in India. Hence, they viewed that the Indian commodity market is not well organized [3]. Iqbal et al. (2013) measured the relationship between investors' behaviour and financial market anomalies. The stock anomalies created due to over confidence of investors, overstated reactions, guesstimate and change in the investors' behaviour. Thus, the behaviour of the investors had led to abnormal market conditions [4].

Chen and Chang (2015) identified producers' role, hedge funds, and business entities were determined the price of commodity futures [5]. Erb and Harvey (2016) analyzed the misconceptions of investors when investing in the commodities. The low return was caused due to pitiable financial performance. The study result showed that misunderstanding had created disappointment with the commodity trading [6]. Ftiti et. al (2016) have studied the relationship between delays and delays. The study results showed that there was a relationship between delays and delays. Moreover, commodity market is a prime reason for fluctuations in the credit markets [7].

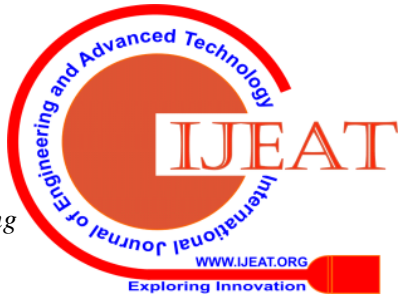




\section{Attitude of Individual Investors towards Commodity Trading in Disruptive Technological Era}

Jena, et al. (2016) have identified that commodity prices was linked with the commodity prices. But, the commodity prices were negatively correlated with the bond prices [8]. Mellios et al. (2016) examined that risk factor determined the size and nature of investment [9]. Periyasamy (2016) identified the investors' awareness programme had significantly influenced on investment decision making among the potential investors in India [10].

Han, L., et al. (2017) viewed that the investors had to improve their attention and to analyze market information for sinking the opportunity of arbitrage. Hence, the investors had more concern about the impact of the market efficiency for promoting the stocks' preservation [11]. Monga et al (2016) and Vasan (2018) identified that investors had preferred to invest in jewelry than other investment avenues like gold bars and coins, gold ETFs, etc. Hence, investors had given priority to safety than earning higher profits [12] [13].

\section{OBJECTIVES OF THE STUDY}

i) To know the investor's preference and reasons for investing in the commodity market; and

ii) To measure the satisfaction of investors towards the commodity market.

\section{RESEARCH METHODOLOGY}

The present study is formed based on the qualitative data collected under the survey method. The primary data has been collected through questionnaire. The secondary data pertaining to study has been collected from the books, reports, journals, web portals, etc. The investors are highly scattered in the study area. So, the snowball sampling method is adopted to select the sample investors in the western region of Tamilnadu. The sample size of 130 investors has been chosen for the study. The statistical tools such as descriptive statistics, Friedman's test, and ' $t$ ' test used to present the data collected from the investors of commodity market.

\section{DATA ANALYSIS AND RESULTS}

In this part, investors' preference and satisfaction with commodity trading have been presented.

\section{Investors' Preference}

Now-a-days more people are preferred to invest in the commodity exchanges than other investment avenues. Investment is a sacrifice made for future reward. Keeping in this view, the investors' investment pattern has been analyzed with respect to sources of information, amount invested in commodity market and other than commodities, preferred commodity, experience in dealing commodities, objectives of investment in commodity market, techniques for managing risks, reasons for investing in commodity and problems in commodity trading.

Table 1: Sources of Information

\begin{tabular}{|l|c|c|}
\hline Sources of Information & Frequency & Percent \\
\hline Internet & 22 & 16.9 \\
\hline Broker's advice & 26 & 20.0 \\
\hline Television & 40 & 30.8 \\
\hline Friendsand relatives & 32 & 24.6 \\
\hline Newspapers & 4 & 3.1 \\
\hline
\end{tabular}

\begin{tabular}{|l|c|c|}
\hline Investors' association & 6 & 4.6 \\
\hline Total & 130 & 100.0 \\
\hline
\end{tabular}

16.9 percent of the investors have known through internet, 20.0 percent through brokers, 30.8 percent through television, 24.6 percent through friends and relatives and 3.1 percent of the respondents through newspapers and 4.6 percent through investors' association.

Table 2: Amount Invested in the Commodity Market

\begin{tabular}{|l|c|c|}
\hline \multicolumn{1}{|c|}{ Amount Invested } & Frequency & Percent \\
\hline Below ₹ $1,00,000$ & 43 & 33.1 \\
\hline ₹ $1,00,001-2,00,000$ & 43 & 33.1 \\
\hline ₹ $2,00,001-3,00,000$ & 28 & 21.5 \\
\hline ₹ $2,00,001-3,00,000$ & 16 & 12.3 \\
\hline Total & 130 & 100.0 \\
\hline
\end{tabular}

The amount invested in commodity market shows that 33.1 percent of the investors have invested less than ₹1,00,000, 33.1 percent invested $₹ 1,00,001-2,00,000$ and 21.5 percent invested ₹2,00,001-3,00,000 and 3.3 percent have invested more than ₹2,00,001-3,00,000 in the commodity market.

Table 3: Amount Invested in Other than Commodities

\begin{tabular}{|l|c|c|}
\hline \multicolumn{1}{|c|}{ Options } & Frequency & Percent \\
\hline Equity & 21 & 16.2 \\
\hline Mutual Funds & 36 & 27.7 \\
\hline Bonds / Debentures & 34 & 26.7 \\
\hline Banks & 28 & 21.5 \\
\hline Others & 11 & 1.9 \\
\hline Total & 130 & 100.0 \\
\hline
\end{tabular}

16.2 percent are invested in equities, 27.7 percent are invested in mutual funds, 26.7 percent are invested in bonds/ debentures, 21.5 percent are invested in banks and 1.9 percent of the investors have invested in other avenues such as insurance, real estate, business, etc.

Table 4: Preferred Commodity

\begin{tabular}{|l|c|c|}
\hline Commodity Products & Frequency & Percent \\
\hline Agro based & 20 & 15.4 \\
\hline Energy & 10 & 7.7 \\
\hline Metal & 38 & 29.2 \\
\hline Precious metal & 44 & 33.8 \\
\hline Oil and oil seeds & 12 & 9.2 \\
\hline Spices & 6 & 4.6 \\
\hline Total & 130 & 100.0 \\
\hline
\end{tabular}

The preferred commodity divulges that 15.4 percent have preferred to invest in the agro-based commodities, 7.7 percent are energy, 29.2 percent are metal, 33.8 percent are precious metal, 9.2 percent are oil and oil seeds and 4.6 are preferred spices.

Table 5: Experience in Dealing Commodities

\begin{tabular}{|l|c|c|}
\hline \multicolumn{1}{|c|}{ Number of years } & Frequency & Percent \\
\hline Less than 1 year & 38 & 29.2 \\
\hline 1 to 5 years & 45 & 34.6 \\
\hline 5 to 10 years & 23 & 17.7 \\
\hline
\end{tabular}




\begin{tabular}{|l|c|c|}
\hline More than 10 years & 24 & 18.5 \\
\hline Total & 130 & 100.0 \\
\hline
\end{tabular}

Experience in dealing commodities shows that 29.2 percent of the investors are having experience of less than 1 year, 34.6 percent are between $1-5$ years, 17.7 percent are 5-10 years and 18.5 percent of the investors are having more than 10 years of experience in the filed of commodity trading.

Table 6: Objective of Investment in Commodity Market

\begin{tabular}{|l|c|c|}
\hline \multicolumn{1}{|c|}{ Investment Objectives } & Frequency & Percent \\
\hline Growth and income & 30 & 23.7 \\
\hline $\begin{array}{l}\text { Income and capital } \\
\text { preservation }\end{array}$ & 40 & 30.8 \\
\hline Long tearm growth & 35 & 26.9 \\
\hline Short term growth & 25 & 18.6 \\
\hline \multicolumn{1}{|c|}{ Total } & 130 & 100.0 \\
\hline
\end{tabular}

The objective of investment made in the commodity market depicts that 23.7 percent have invested for growth and income, 30.8 percent for income and capital preservation, 26.9 percent are invested for long-term growth and 18.6 percent have invested to reap the benefits of short-term growth.

Table 7: Techniques for Managing the Risks in Commodity Market

\begin{tabular}{|l|c|c|c|c|c|}
\hline \multicolumn{1}{|c|}{ Variables } & $\overline{\mathbf{x}}$ & $\sigma$ & $\begin{array}{c}\text { Mean } \\
\text { Rank }\end{array}$ & $\begin{array}{c}\chi^{2} \\
\text { Test }\end{array}$ & Sig \\
\hline Avoidance & 3.70 & 2.010 & 3.71 & \multirow{2}{*}{7.406} & .000 \\
\cline { 1 - 4 } Exit with minimum loss & 3.95 & 1.952 & 3.97 & & \\
\cline { 1 - 4 } Diversification & 4.31 & 2.042 & 4.35 & & \\
\cline { 1 - 4 } Average Down & 4.17 & 2.054 & 4.20 & & \\
\cline { 1 - 4 } Ignore the risk & 3.92 & 2.014 & 3.96 & & \\
\cline { 1 - 4 } Hedging & 3.88 & 2.108 & 3.91 & & \\
\cline { 1 - 4 } Market trend & 3.88 & 1.778 & 3.90 & & \\
\hline
\end{tabular}

The Friedman's $\chi^{2}$ test results shows that there is a variation $(\mathrm{P}=<0.05)$ in the techniques adapted to manage the risks in the commodity market. The mean ranks publicized that 'Diversification' is a prime strategy adopted to manage the risk (Mean Rank=4.35) followed by minimum loss (Mean Rank=3.97) and hedging (Mean Rank=3.91).

Table 8: Reasons for Investing in Commodity Market

\begin{tabular}{|l|c|c|c|c|c|}
\hline \multicolumn{1}{|c|}{ Variables } & $\overline{\mathbf{x}}$ & $\sigma$ & $\begin{array}{c}\text { Mean } \\
\text { Rank }\end{array}$ & $\chi^{2}$ Test & Sig \\
\hline Low Risk & 3.19 & 1.289 & 3.18 & \multirow{2}{*}{9.265} & \multirow{2}{*}{.000} \\
\hline Low Investment & 2.69 & 1.534 & 2.68 & & \\
\cline { 1 - 5 } High Return & 2.95 & 1.435 & 2.95 & & \\
High Liquidity & 3.18 & 1.488 & 3.19 & & \\
\cline { 1 - 4 } Speculation & 2.99 & 1.279 & 2.99 & & \\
\hline
\end{tabular}

The results of Friedman's $\chi^{2}$ test explores that there is a variation $(\mathrm{P}=<0.05)$ in the reasons for investing in the commodity market. The mean rank shows that low risk is a prime reason for investing in commodity market (Mean Rank=3.19) followed by high return (Mean Rank=2.95), speculation (Mean Rank=2.99) and low investment (Mean Rank=2.69).

Table 9: Problems in Commodity Trading

\begin{tabular}{|l|c|c|c|c|c|}
\hline \multicolumn{1}{|c|}{ Variables } & $\overline{\mathbf{x}}$ & $\sigma$ & $\begin{array}{c}\text { Mean } \\
\text { Rank }\end{array}$ & $\chi^{2}$ Test & Sig \\
\hline Volatile & 3.13 & 1.522 & 3.10 & 4.405 & .000 \\
\cline { 1 - 5 } High contract size & 2.78 & 1.520 & 2.75 & & \\
\cline { 1 - 4 } $\begin{array}{l}\text { Standardized } \\
\text { contracts }\end{array}$ & 3.07 & 1.410 & 3.02 & & \\
\cline { 1 - 4 } Complexity & 3.08 & 1.270 & 3.07 & & \\
\cline { 1 - 4 } $\begin{array}{l}\text { Returns not } \\
\text { assured }\end{array}$ & 3.12 & 1.429 & 3.07 & & \\
\hline
\end{tabular}

The results of Friedman's $\chi^{2}$ test reveals that there is a variation $(\mathrm{P}=<0.05)$ in the problems faced by the investors of commodity market. The mean ranks depicts that 'market volatility' is a daunting problem faced by the investors of commodity market (Mean Rank=3.13) followed by Returns not assured (Mean Rank=3.12) complexity (Mean Rank=3.08) standardized contracts (Mean Rank=3.07) and high contract size (Mean Rank= 2.78).

\section{Investors' Satisfaction with Performance of Commodity} Trading

The satisfaction of investors towards commodity trading has been analyzed with the help of one-sample ' $t$ ' test.

Table 10: Investors' Satisfaction on Commodity Trading

\begin{tabular}{|l|c|c|c|c|}
\hline \multicolumn{1}{|c|}{ Variables } & $\overline{\mathbf{x}}$ & $\sigma$ & $\mathbf{t}$ & Sig. \\
\hline Return Earned & 4.42 & .913 & 17.672 & .000 \\
\hline Level of Risk & 3.12 & 1.093 & 1.284 & .000 \\
\hline $\begin{array}{l}\text { Diversified } \\
\text { investments } \\
\text { options }\end{array}$ & 4.15 & 1.264 & 6.800 & .000 \\
\hline Liquidity aspects & 3.36 & 1.270 & 3.246 & .000 \\
\hline $\begin{array}{l}\text { Brokers' } \\
\text { Information }\end{array}$ & 3.20 & 1.389 & 1.642 & .000 \\
\hline $\begin{array}{l}\text { Investors } \\
\text { Protection } \\
\text { Measures }\end{array}$ & 3.34 & 1.350 & 2.859 & .000 \\
\hline $\begin{array}{l}\text { Experts' Guidance } \\
\text { (through media) }\end{array}$ & 4.01 & 1.283 & 5.648 & .000 \\
\hline $\begin{array}{l}\text { Contract } \\
\text { Settlement }\end{array}$ & 3.39 & 1.210 & 3.695 & .000 \\
\hline Role of BSE/NSE & 3.22 & 1.371 & 1.855 & .000 \\
\hline Role of SEBI & 3.03 & 1.430 & .245 & .000 \\
\hline
\end{tabular}

The ' $t$ ' values for all the variables of investors' satisfaction with commodity market are statistically significant $(\mathrm{P}=<.05)$. It indicates that there is difference in the satisfaction level of the investors towards commodity trading. The mean value shows that the investors are highly satisfied with the returns earned, and diversified products guidance of the experts through media. The investors have moderate level of satisfaction with level of risk, liquidity aspects, information provided by the brokers, investors' protection measures, settlement of the contracts, role of stock exchange (BSE, NSE, etc.) and role of SEBI

\section{CONCLUSION}

The study has been analyzed individual investors' attitude and satisfaction towards trading in the commodity market.
Blue Eyes Intelligence Engineering \& Sciences Publication 


\section{Attitude of Individual Investors towards Commodity Trading in Disruptive Technological Era}

This study helps to understand the personal choices and preferences of the individual investors. It identified that majority of investors are came to know about commodity trading through television. Investors are invested in commodities as well as other diversified investment avenues. Low risk is a prime reason for investing in the commodities. The market volatility is a daunting problem faced by the investors of commodity market.

The investors are highly satisfied with the returns from commodity trading. The study suggested that investors have to learn more about the commodity market for safest trading. The regulators of commodity market and government should strengthen its rules for protecting the investors. Thus, new schemes are to be introduced to attract the non-traders and small investors.

\section{REFERENCES}

1. Bring Bush. (2017). Investor Protection and Information is an Important Pillar of Agenda and Post-Crisis Rule Control - The Way forward. Sector and Economic Outlook, 56(1), 29-60.

2. Vasan, M. (2018). Attitude of Customers towards Branded and Non-branded Gold Jewellers - A Study. International Journal of Reviews and Research in Social Science, 6(3), 155-160.

3. Kapil, Sheba \& Kanval Nyan Kapil (2010). Merchandise Trade Advisor for the Indian Commodity Market. International Journal of the Five, 124-137.

4. Iqbal, S., Hussain, N., Latif, M \& Aslam, S. (2013). Types of Investors and Irregularities in Financial Markets: Comparisons of Individual and Foreign Investors, and their Role in Decision-Making in Investment. Journal of Scientific Research, 17(11), 1591-1596.

5. Chen, Y. \& Chang, Y.K. (2015). Investor Structure and Information Efficiency of Future Commodity Prices. Review of International Monetary Fund, 42, 358-367.

6. Erb, C.B, \& Harvey. (2016). Misleading Confusion about Future Investment in Raw Materials. Financial Analyst, 72(4), 26-35.

7. Ftiti, Z., Kablan, S. \& Guesmi, K. (2016). What can we learn about commodities and credit cycles? Evidence from African Exporting Countries. Energy Economics, 60, 313-324.

8. Jena, Pratap Kumar \& Phannidra Goyari. (2016). Real Relationship between Commodities, Stocks and Credit Cards in India: DCC Model Analysis. IUP Journal of Applied Finance, 22(1), 37.

9. Mellios, C., Six, P. \& Lai, A.N. (2016). Dynamic Expectations and Curbs of Future Commodity Markets with Stochastic Comfort Income. European Data on Operational Data, 250(2), 493-504.

10. Periyasamy, S. (2016). Impact of Investor Information Programs on Potential Investors on the Stock Exchange of India. International Journal of Research, Information, and Governance Research, 6(2), 21-23.

11. Han, L., Li, Z., \& Yin, L. (2017). Impact of Investor Attention on Future Commodity Markets. Newspapers on Futures Market. 12.

12. Monga, O.P., Dawra, S., Monga, A. \& Bansal, A.A.K. (2016). Investor Perspectives on Gold Investing: Some Reflections. International Journal of Engineering Engineering Business and Enterprise, 17(1), 5-9.

13. Vasan, M. (2015).Gold Buyers' Behaviour, India: New Delhi, EduPedia Publications. 